\title{
Selection of Brahman crossbred-breeding bulls based on phenotypic performance
}

\author{
MM Haque $^{1}$, MA Hoque* ${ }^{1}$, NG Saha ${ }^{1,2}$, AKFH Bhuiyan $^{1}$, MM Hossain $^{3}$, MA Hossain ${ }^{4}$ \\ ${ }^{1}$ Department of Animal Breeding and Genetics, Bangladesh Agricultural University, Mymensingh; ${ }^{2}$ Department \\ of General Animal Science and Nutrition, Patuakhali Science and Technology University, \\ Patuakhali, ${ }^{3}$ Department of Animal Science, Bangladesh Agricultural University, Mymensingh, ${ }^{4}$ Upazila Livestock \\ Office, Chirirbandar, Dinajpur, Bangladesh
}

\begin{abstract}
A beef breed development project was carried out in the Department of Livestock Services (DLS) in 2009 in selected areas of Bangladesh. Under this project, semen of Brahman bulls were imported from the USA and used to inseminate indigenous cows to produce graded calves. The present study was undertaken to select graded Brahman bulls of the aforesaid project for breeding purpose. Using the data of Brahman grade- 1 population, 4 (four) bulls were selected based on external appearance, phenotypic performance and libido. Records on 233 Brahman grade-1 calves (127 male and 106 female) were analyzed by SAS computer program. Birth weight, yearling weight and average daily gain were estimated by considering sex and area groups. The birth weight was found to be $22.25 \pm 5.60 \mathrm{Kg}$ for male and $20.33 \pm 3.88 \mathrm{Kg}$ for female calves (average $21.38 \pm 4.98 \mathrm{Kg}$ ). The yearling weight of male and female calves was found to be $222.07 \pm 73.21$ and $191.76 \pm 69.04 \mathrm{Kg}$, respectively. Highest yearling weight and average daily gain were found in Charghat $(401.11 \pm 39.75 \mathrm{~kg}$ and $1034.82 \pm 107.90 \mathrm{~g}$, respectively) while lowest values were in Thakurgaon area $(152.69 \pm 52.74 \mathrm{Kg} 369.42 \pm 141.94 \mathrm{~g}$, respectively). The average daily gain male and female calves were 547.42 \pm 193.7 and $470.34 \pm 184.52$ $g$, respectively. Area and sex had highly significant $(p<0.001)$ effects on birth weight, yearling weight and average daily gain of calves. The average daily gain of four selected graded Brahman bull calves was $731 \mathrm{~g}$. The estimated selection differential and selection intensity for average daily gain of the four bulls were $183.53 \mathrm{~g}$ and 2.263 , respectively. The growth performance along with estimated selection intensity and selection differential for average daily gain indicated that these selected graded Brahman breeding bulls may generate a good opportunity to improve indigenous cattle for beef purposes.
\end{abstract}

Key words: Brahma bull, growth performance, selection deferential, selection intensity

Bangladesh Animal Husbandry Association. All rights reserved.

Bang. J. Anim. Sci. 2011. 41 (2): 60-66

\section{Introduction}

Bangladesh has a great demand of meat and the economic environment of today's beef business is challenging. Commercial cow-calf producers are being faced with optimizing a number of economically important traits, while simultaneously reducing costs of production in order to remain competitive. Traits such as reproduction, growth and maternal ability; all are influencing the productivity and profitability of the beef enterprise. To fulfill above requirement for beef industry, well adopted beef cattle genotype should be developed in Bangladesh. The cattle resources of Bangladesh are mostly of indigenous type (Bos indicus) with substantial number of crossed Sindhi, Sahiwal, Jersey and HolsteinFriesian. A few varieties of cattle like Red Chittagong, Pabna Milking Cattle, Munshiganj, Madaripur and North Bengal grey etc are localized in some areas of the country, and which are mainly being rearing for milk and to some extent for meat. As there is no beef type animal in the country, the farmers are frequently being involved in fattening of either local or upgraded dairy crossed bull calves for increasing the beef production in Bangladesh.

Considering weather, agro-climatic condition, heat tolerance, disease and insect resistance, longevity, grazing ability, calving ease, mothering ability and management, Brahman breed is considered to be the most suitable and compatible beef breed in tropical and sub-tropical region. A number of American beef breeds have been developed using Brahman genotypes e.g. Brangus, Beefmaster, etc. Brahman bulls weigh from 800 to $1,100 \mathrm{~kg}$ and cows from 500 to 700 $\mathrm{kg}$ and calves grow very rapidly afterward compared to other breeds (Colditz and Kellaway 1972). The Brahmans are known to be well 
adapted in regions of harsh climates and poor grazing. They have a greater ability to withstand heat. They have mere sweat glands and the ability to sweat freely through the pores of the skin, which contributes to their heat tolerance. Their oily skin thought to help repel pests and insects along with a smooth coat. They are also more resistant to parasites and diseases. For these characteristics Brahmans have been extensively crossed with cattle in tropical areas of the world to explore their advantages in hot climates.

The economic benefits obtained from a crossbreeding system can be great, but efficacy of the system depends upon the proper mating of cows to superior and unrelated bulls (Olson 2011). If proper crossbreeding program can be run then interested farmer can have suitable animal for beef production and the country will get some more meat as animal protein.

Conversely, the breeds that are close to indigenous stock always bear greater importance for that particular country or region because they can thrive easily in local condition. It is reported that indigenous cattle of the country are also more disease resistant and capable to thrive well in harsh condition (Majid et al. 1992). Moreover, majority of the poor farmers are more habituated to manage their indigenous stock by following low input management system. Therefore, upgraded Brahman crossed bull may be more adaptable to our agro-climatic condition for beef production.

Considering the above facts, the present study was undertaken to select Brahman crossbred breeding bulls from grade- 1 population taking the regional influence into account and to estimate the selection differential and selection intensity to predict the genetic gain for the next generation.

\section{Materials and methods}

\section{Experimental animals}

A beef breed development program entitled "Beef breed improvement project" is running in different selected areas of Bangladesh by the Government of the Peoples' Republic of Bangladesh under the Department of Livestock Services (DLS). In this project, semen of Brahman bulls was imported from the USA in 2009 (Bull ID BR40, BR524, BR522, BR525, 14BR41 and BR10) This imported semen was used to inseminate indigenous cows to obtain graded progeny in the selected regions.
With the collaboration of DLS, Faculty of Animal Husbandry, Bangladesh Agricultural University (BAU) has started a sub-project entitled "Innovative research on livestock and poultry to increase milk, meat and egg production in Bangladesh". In the present research, 4 (four) Brahman crossbred (graded) breeding bulls have been selected from those crossbred population-1 $\left(F_{1}\right)$. Bulls have been selected on the basis of average daily gain, physical appearance and libido. The selected bulls are now being rearing at the artificial insemination center of BAU. Collected semen of those bulls are being used to inseminate indigenous cow to improve beef production potentialities.

\section{Population size and data structure}

Indigenous cows were inseminated with the Brahman semen in the selected areas of Bangladesh and a total of 233 crossbred (graded) calves in which 127 of males and 106 of females were born. The name of the selected areas and the population size are presented in Table 1.

Table 1. Selected areas and crossbred population

\begin{tabular}{lc|lc}
\hline Area & No. calves & \multicolumn{1}{|c}{ Area } & No. calves \\
\hline CCBDF & 63 & Tungipara & 08 \\
Chirirbandor & 20 & Kustia & 10 \\
Pirganj & 29 & Jessore & 08 \\
Shariakandi & 08 & Moulovibazar & 12 \\
Belkuchi & 09 & Charghat & 08 \\
Chouhali & 14 & Thakurgaon & 44 \\
\hline
\end{tabular}

The different information like artificial insemination date, calving date, birth weight, weaning weight, yearling weight etc. were collected from the herdbook maintained at the Upazila Livestock Office with the help of appointed animal recorders in the respective selected areas.

\section{Data entry, reliability test and sorting}

After completing the pre-tabulation task of the collected data, records of crossbred progenies were entered in Excel sheets of Microsoft office computer program. The collected data were tested for their normal distribution using Statistical Analysis System (SAS, Version 6.12) method and abnormal data were omitted from the data sheets.

\section{Statistical Analysis}

Before selecting breeding bulls, effects of different areas and sex of calves on crossbred 


\section{Brahman crossbred bull selection}

performance were estimated. The sorted data were analyzed to obtain ANOVA by Generalized Linear Model using Statistical Analysis System (SAS, Version 6.12) computer package. Least Significant Difference (LSD) test was performed to separate mean values.

\section{Results}

\section{Birth weight}

The mean values along with standard deviations (SD) of birth weight of Brahman crossbred calves are shown in Table 2. The highest birth weight of $26.12 \pm 8.26 \mathrm{~kg}$ was observed in Tungipara and the lowest one of $16.50 \pm 4.17 \mathrm{~kg}$ in Sariakandi. Relatively similar birth weight was obtained from Chirirbandar, Kustia, Jessore, Belkuchi, Charghat and Pirganj, and ranged from 20.60 1 1.69$22.60 \pm 3.41 \mathrm{~kg}$. The calves from Thakurgaon and Chouhali were low in birth weight $(17.81 \pm 2.13$ and $19.44 \pm 6.36 \mathrm{~kg}$, respectively).

Table 2. Mean $\pm S D$ of birth weight $(\mathrm{kg})$ of crossbred calves

\begin{tabular}{|c|c|c|c|}
\hline Area & Pooled & Male & Female \\
\hline CCBDF & $\begin{array}{r}23.21^{\mathrm{abc}} \\
\pm 4.57(63) \\
\end{array}$ & $\begin{array}{c}23.95^{\mathrm{abc}} \\
\pm 5.21 \text { (37) }\end{array}$ & $\begin{array}{c}22.51^{\mathrm{a}} \\
\pm 3.27(26) \\
\end{array}$ \\
\hline Chirirbandar & $\begin{array}{c}20.60^{\text {cd }} \\
\pm 1.69(20)\end{array}$ & $\begin{array}{c}20.71^{\text {abcde }} \\
\pm 1.43 \text { (14) }\end{array}$ & $\begin{aligned} & 20.33^{\mathrm{a}} \\
& \pm 2.33(6) \\
&\end{aligned}$ \\
\hline Pirganj & $\begin{array}{r}22.60^{\mathrm{abc}} \\
\pm 3.41(29)\end{array}$ & $\begin{array}{r}23.26^{\mathrm{abc}} \\
\pm 3.57 \text { (17) }\end{array}$ & $\begin{array}{r}21.66^{\mathrm{ab}} \\
+3.08(12) \\
\end{array}$ \\
\hline Sariakandi & $\begin{array}{c}16.50^{C} \\
\pm 4.17(8)\end{array}$ & $\begin{array}{c}18.33^{\text {cde }} \\
\pm 7.23 \text { (4) }\end{array}$ & $\begin{array}{c}18.25^{\mathrm{bc}} \\
\pm 4.99 \text { (4) }\end{array}$ \\
\hline Belkuchi & $\begin{array}{c}21.70^{\text {bcd }} \\
\pm 5.60(9)\end{array}$ & $\begin{array}{r}26.43^{\mathrm{e}} \\
\pm 1.20(4)\end{array}$ & $\begin{array}{l}19.33^{\mathrm{a}} \\
\pm 5.43(8) \\
\end{array}$ \\
\hline Chouhali & $\begin{aligned} & 19.44^{\mathrm{bcd}} \\
& \pm 6.36(14) \\
&\end{aligned}$ & $\begin{array}{c}18.33^{\text {cde }} \\
\pm 7.23(6)\end{array}$ & $\begin{array}{c}20.27^{\mathrm{a}} \\
\pm 6.00(8)\end{array}$ \\
\hline Tungipara & $\begin{array}{c}26.12^{\mathrm{a}} \\
\pm 8.26(8)\end{array}$ & $\begin{array}{r}27.80^{\text {cde }} \\
\pm 10.20(6) \\
\end{array}$ & $\begin{array}{c}23.33^{\mathrm{a}} \\
\pm 3.51(2)\end{array}$ \\
\hline Kustia & $\begin{aligned} & 21.00^{\mathrm{cd}} \\
& \pm 3.65(10) \\
&\end{aligned}$ & $\begin{array}{c}19.50^{\text {bcde }} \\
\pm 9.19(4)\end{array}$ & $\begin{array}{c}21.37^{\mathrm{ab}} \\
\pm 2.06(8)\end{array}$ \\
\hline Jessore & $\begin{array}{r}21.25^{\mathrm{bcd}} \\
\pm 21.25 \text { (8) }\end{array}$ & $\begin{array}{l}22.16^{\text {abcd }} \\
\pm 3.12(7)\end{array}$ & $\begin{array}{c}18.50^{\mathrm{a}} \\
\pm 0.70(4)\end{array}$ \\
\hline $\begin{array}{l}\text { Moulovi- } \\
\text { Bazar }\end{array}$ & $\begin{aligned} & 25.25^{\mathrm{ab}} \\
&+ 7.73(12) \\
&\end{aligned}$ & $\begin{array}{c}26.87^{\mathrm{ab}} \\
\pm 8.24 \text { (8) }\end{array}$ & $\begin{array}{c}22.00^{\mathrm{a}} \\
\pm 6.27(4) \\
\end{array}$ \\
\hline Charghat & $\begin{array}{c}22.00^{\mathrm{bc}} \\
\pm 5.65(8)\end{array}$ & $\begin{array}{l}22.16^{\text {bcda }} \\
\pm 6.04(6)\end{array}$ & $\begin{array}{c}21.50^{\mathrm{ab}} \\
\pm 6.36(2)\end{array}$ \\
\hline Thakurgaon & $\begin{array}{c}17.81^{\mathrm{e}} \\
+2.13(44)\end{array}$ & $\begin{array}{r}18.26^{\text {cde }} \\
\pm 2.20 \text { (19) }\end{array}$ & $\begin{array}{c}17.48^{\mathrm{b}} \\
\pm 2.06(25)\end{array}$ \\
\hline
\end{tabular}

CCBDF, Central Cattle Breeding and Dairy Farm; Means with different superscript in the same column differ significantly $(p<0.001)$; Figures in the parentheses indicate the number of observation
Considering the sex, mean values along with their standard deviations of birth weight of male and female calves are also shown in Table 2. The highest birth weight of male calves was $27.80 \pm 10.20 \mathrm{~kg}$ in Tungipara and lowest one was in Thakurgaon $(18.26 \pm 2.20 \mathrm{~kg})$. Similarly, the highest and lowest birth weight for female calves was $23.33 \pm 3.31 \mathrm{~kg}$ and $17.48 \pm 2.06 \mathrm{~kg}$ in Tungipara and Thakurgaon, respectively. The average birth weight of Brahman crossed ignoring sex was $21.38 \pm 4.98 \mathrm{~kg}$, and mean for male and female calves were $22.25 \pm 5.60$ and $20.33 \pm 3.88$ $\mathrm{Kg}$, respectively (Table 5 ).

Table 3. Mean \pm SD of yearling weight $(\mathrm{kg})$ of crossbred calves

\begin{tabular}{|c|c|c|c|}
\hline Area & Pooled & Male & Female \\
\hline$\overline{C C B D F}$ & $\begin{array}{c}203.78^{\mathrm{cd}} \\
\pm 47.56 \\
(53)\end{array}$ & $\begin{array}{c}213.00^{\text {cd }} \\
\pm 48.73 \\
(30)\end{array}$ & $\begin{array}{c}191.75^{b c} \\
\pm 44.13 \\
(23)\end{array}$ \\
\hline Chirirbandar & $\begin{array}{c}215.45^{\mathrm{cd}} \\
\pm 43.17 \\
(20)\end{array}$ & $\begin{array}{c}215.86^{\mathrm{cd}} \\
\pm 50.38 \\
(14)\end{array}$ & $\begin{array}{c}214.49^{b c} \\
\pm 21.99 \\
(6)\end{array}$ \\
\hline Pirganj & $\begin{array}{c}218.65^{\mathrm{cd}} \\
\pm 53.22 \\
(29)\end{array}$ & $\begin{array}{c}222.89^{\mathrm{cd}} \\
\pm 63.03 \\
(17)\end{array}$ & $\begin{array}{c}212.64^{b c} \\
\pm 36.95 \\
(12)\end{array}$ \\
\hline Sariakandi & $\begin{array}{c}168.28^{\mathrm{de}} \\
\pm 32.99 \\
(8)\end{array}$ & $\begin{array}{c}189.16^{\mathrm{d}} \\
\pm 21.27 \\
(4)\end{array}$ & $\begin{array}{c}147.40^{c} \\
\pm 30.41 \\
(4)\end{array}$ \\
\hline Belkuchi & $\begin{array}{c}254.15^{\mathrm{bc}} \\
\pm 109.84 \\
\quad(9)\end{array}$ & $\begin{array}{c}304.93^{\mathrm{ab}} \\
\pm 120.25 \\
\quad(1)\end{array}$ & $\begin{array}{c}228.77^{b} \\
\pm 105.83 \\
\quad(8)\end{array}$ \\
\hline Chouhali & $\begin{array}{c}177.72^{\mathrm{de}} \\
\pm 59.15 \\
(10)\end{array}$ & $\begin{array}{c}189.16^{\mathrm{d}} \\
\pm 21.27 \\
(40\end{array}$ & $\begin{array}{c}170.09^{c} \\
\pm 76.50 \\
\quad(6)\end{array}$ \\
\hline Tungipara & $\begin{array}{c}288.80^{b} \\
\pm 85.17 \\
(8)\end{array}$ & $\begin{array}{c}324.24^{\mathrm{ab}} \\
\pm 58.56 \\
(5)\end{array}$ & $\begin{array}{c}229.75^{b c} \\
\pm 100.80 \\
(3)\end{array}$ \\
\hline Kustia & $\begin{array}{c}215.87^{\mathrm{cd}} \\
\pm 46.77 \\
(10)\end{array}$ & $\begin{array}{c}281.82^{b c} \\
\pm 46.16 \\
(2)\end{array}$ & $\begin{array}{c}199.38^{b c} \\
\pm 30.89 \\
(8)\end{array}$ \\
\hline Jessore & $\begin{array}{c}156.13^{\mathrm{e}} \\
\pm 41.15 \\
(8)\end{array}$ & $\begin{array}{c}152.58^{\mathrm{d}} \\
\pm 43.54 \\
(7)\end{array}$ & $\begin{array}{c}166.80^{c} \\
\pm 44.15 \\
\quad(1)\end{array}$ \\
\hline Moulovi- & $300.23^{b}$ & $313.17^{a b}$ & $270.03^{b}$ \\
\hline Bazar & $\begin{array}{c} \pm 53.98 \\
(10)\end{array}$ & $\begin{array}{c} \pm 54.85 \\
(7)\end{array}$ & $\begin{array}{c} \pm 46.20 \\
(3)\end{array}$ \\
\hline Charghat & $\begin{array}{c}401.11^{a} \\
\pm 39.75 \\
(5)\end{array}$ & $\begin{array}{c}378.26^{\mathrm{a}} \\
\pm 34.6 \\
(3)\end{array}$ & $\begin{array}{c}435.38^{\mathrm{a}} \\
\pm 1.76 \\
(2)\end{array}$ \\
\hline Thakurgaon & $\begin{array}{c}152.69^{\mathrm{e}} \\
\pm 52.74 \\
(40)\end{array}$ & $\begin{array}{c}168.74^{d} \\
\pm 56.54 \\
(18)\end{array}$ & $\begin{array}{c}139.56^{c} \\
\pm 46.66 \\
(22)\end{array}$ \\
\hline
\end{tabular}

CCBDF, Central Cattle Breeding and Dairy Farm; Means with different superscript in the same column differed significantly $(p<0.001)$; Figures in the parenthesis indicate the number of observation 
Table 4. Mean \pm SD of average daily gain ( $g$ ) of crossbred calves

\begin{tabular}{|c|c|c|c|}
\hline Area & Pooled & Male & Female \\
\hline \multirow[t]{3}{*}{ CCBDF } & $494.30^{\mathrm{de}}$ & $516.73^{\text {cd }}$ & $465.06^{\mathrm{bc}}$ \\
\hline & \pm 125.35 & \pm 128.18 & \pm 117.90 \\
\hline & (53) & (30) & (23) \\
\hline \multirow[t]{2}{*}{ Chirirbandar } & $533.85^{\mathrm{cd}}$ & $534.66^{\mathrm{cd}}$ & $531.95^{b c}$ \\
\hline & $\begin{array}{c} \pm 118.51 \\
(20)\end{array}$ & $\begin{array}{c} \pm 138.51 \\
(14)\end{array}$ & $\begin{array}{c} \pm 59.02 \\
(6)\end{array}$ \\
\hline \multirow[t]{2}{*}{ Pirganj } & $537.11^{\text {cd }}$ & $546.92^{\mathrm{cd}}$ & $523.22^{b c}$ \\
\hline & $\begin{array}{c} \pm 144.45 \\
(29)\end{array}$ & $\begin{array}{c} \pm 171.83 \\
(17)\end{array}$ & $\begin{array}{c}99.03 \\
(12)\end{array}$ \\
\hline \multirow[t]{2}{*}{ Sariakandi } & $415.83^{\mathrm{de}}$ & $477.84^{d}$ & $353.82^{c}$ \\
\hline & $\begin{array}{c} \pm 90.44 \\
(8)\end{array}$ & $\begin{array}{c} \pm 60.51 \\
(4)\end{array}$ & $\begin{array}{c} \pm 71.91 \\
(4)\end{array}$ \\
\hline \multirow[t]{2}{*}{ Belkuchi } & $636.87^{b c}$ & $763.00^{\mathrm{de}}$ & $573.81^{b}$ \\
\hline & $\begin{array}{c} \pm 288.48 \\
(9)\end{array}$ & $\begin{array}{c} \pm 327.14 \\
(1)\end{array}$ & $\begin{array}{c} \pm 275.74 \\
(8)\end{array}$ \\
\hline \multirow[t]{2}{*}{ Chouhali } & $440.48^{\text {de }}$ & $477.84^{d}$ & $415.57^{c}$ \\
\hline & $\begin{array}{c} \pm 155.54 \\
(10)\end{array}$ & $\begin{array}{c} \pm 60.51 \\
(4)\end{array}$ & $\begin{array}{c} \pm 198.71 \\
(6)\end{array}$ \\
\hline \multirow[t]{2}{*}{ Tungipara } & $719.68^{b}$ & $812.17^{a b}$ & $565.53^{b c}$ \\
\hline & $\begin{array}{c} \pm 223.54 \\
(8)\end{array}$ & $\begin{array}{c} \pm 134.54 \\
(5)\end{array}$ & $\begin{array}{c} \pm 285.78 \\
\text { (3) }\end{array}$ \\
\hline \multirow[t]{2}{*}{ Kustia } & $533.90^{\text {cd }}$ & $718.69^{b c}$ & $487.70^{\mathrm{bc}}$ \\
\hline & $\begin{array}{c} \pm 128.16 \\
(10)\end{array}$ & \pm 101.30 & $\begin{array}{c} \pm 86.36 \\
(8)\end{array}$ \\
\hline \multirow[t]{2}{*}{ Jessore } & $369.56^{\mathrm{e}}$ & $357.31^{d}$ & $406.31^{c}$ \\
\hline & $\begin{array}{c} \pm 113.68 \\
(8)\end{array}$ & $\begin{array}{c} \pm 121.03 \\
(7)\end{array}$ & $\begin{array}{c} \pm 119.02 \\
(1)\end{array}$ \\
\hline Moulovi- & $756.25^{b}$ & $785.99^{\mathrm{ab}}$ & $686.85^{b}$ \\
\hline Bazar & $\begin{array}{c} \pm 130.60 \\
(10)\end{array}$ & $\begin{array}{c} \pm 129.95 \\
(7)\end{array}$ & $\begin{array}{c} \pm 125.59 \\
\text { (3) }\end{array}$ \\
\hline \multirow[t]{2}{*}{ Charghat } & $1034.82^{a}$ & $968.75^{a}$ & $1133.93^{\mathrm{a}}$ \\
\hline & $\begin{array}{c} \pm 107.90 \\
(5)\end{array}$ & $\begin{array}{c} \pm 82.68 \\
(3)\end{array}$ & $\begin{array}{c} \pm 12.62 \\
(2)\end{array}$ \\
\hline \multirow[t]{2}{*}{ Thakurgaon } & $369.42^{e}$ & $411.77^{d}$ & $334.78^{c}$ \\
\hline & $\begin{array}{c} \pm 141.94 \\
(40)\end{array}$ & $\begin{array}{c} \pm 153.60 \\
(18)\end{array}$ & $\begin{array}{c} \pm 124.59 \\
(22)\end{array}$ \\
\hline
\end{tabular}

CCBDF, Central Cattle Breeding and Dairy Farm; Means with different superscript in the same column differed significantly $(p<0.001)$; Figures in the parenthesis indicate the number of observation

\section{Yearling weight}

The yearling weight of male, female and pooled data of Brahman crossbred calves are shown in Table 3. Area has significant effect $(p<0.05)$ on yearling weight of calves. The highest yearling weight of $401.11 \pm 39.75 \mathrm{~kg}$ was observed in Charghat and the lowest one of $152.69 \pm 52.74 \mathrm{~kg}$ in Thakurgaon. Comparatively, almost similar yearling weight was found in CCBDF, Chirirbandar, Kustia and Pirgonj and ranged from $203.78 \pm 47.56$ to $218.65 \pm 53.22 \mathrm{~kg}$. The highest yearling weight of male was $378.26 \pm 34.60 \mathrm{~kg}$ in Charghat and lowest one of $152.58 \pm 43.54 \mathrm{~kg}$ in Jessore. Alike the highest and lowest yearling weight for female was $435.38 \pm 1.76 \mathrm{~kg}$ and
$139.56 \pm 46.66 \mathrm{~kg}$ in Charghat and Jessore, respectively.

\section{Average daily gain}

Mean values of average daily gain of Brahman crossbred calves are presented in Table 4. Using pooled data, the highest gain of $1034.82 \pm 107.90$ $\mathrm{g} /$ day was found in Charghat and the lowest one of $369.42 \pm 141.94 \mathrm{~g}$ in Thakurgaon. Maximum of $968.750 \pm 82.68 \mathrm{~g}$ average daily gain for male calves was obtained in Charghat area, while minimum of $357.31 \pm 121.03 \mathrm{~g}$ in Jessore. However, the mean yearling weight of Brahman crossed male and female was $222.07 \pm 73.21$ and $191.76 \pm 69.04 \mathrm{~kg}$, respectively with pooled value of $208.07 \pm 72.74 \mathrm{~kg}$ (Table 5).

Table 5. Mean \pm SD of birth weight, average daily gain and yearling weight of all calves

\begin{tabular}{llll}
\hline Trait & Male & Female & Pooled \\
\hline BWT & $22.25^{\mathrm{a}}$ & $20.33^{\mathrm{b}}$ & 21.38 \\
$(\mathrm{~kg})$ & $\pm 5.60(127)$ & $\pm 3.88(106)$ & $\pm 4.98(233)$ \\
\hline ADG & $547.42^{\mathrm{a}}$ & $470.34^{\mathrm{b}}$ & 511.81 \\
$(\mathrm{~g} / \mathrm{d})$ & $\pm 193.7(113)$ & $\pm 184.5(97)$ & $\pm 192.9(210)$ \\
\hline YWT & $222.07^{\mathrm{a}}$ & $191.76^{\mathrm{b}}$ & 208.07 \\
$(\mathrm{~kg})$ & $\pm 73.21(113)$ & $\pm 69.04(97)$ & $\pm 72.74(210)$ \\
\hline
\end{tabular}

BWT, birth Weight; ADG, average daily gain; YWT, yearling weight; Means with different superscript in the same column differ significantly $(p<0.001)$

The average daily gain of Brahman crossed male and female calves were 547.42 \pm 193.7 and $470.34 \pm 184.52 \mathrm{~g}$, respectively and population mean was $511.81 \pm 192.95 \mathrm{~g}$ (Table 5).

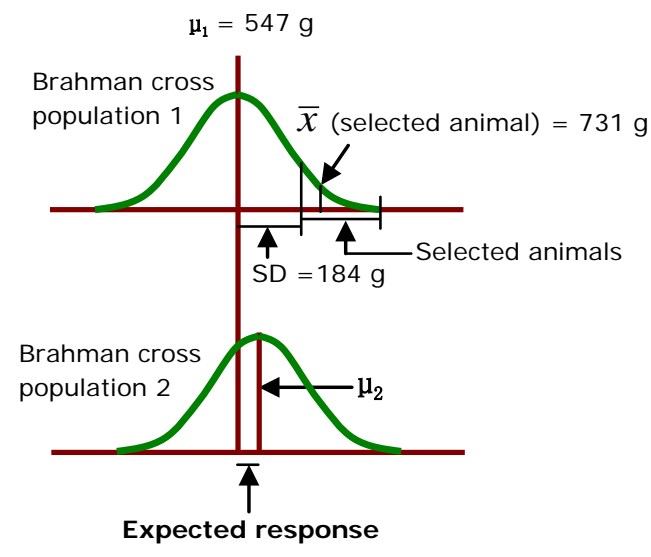

Figure 1. Expected response on average daily gain to selection from population 1 to population 2 (Population size $=233$ (Male $=127 ;$ Female $=106)$ 


\section{Brahman crossbred bull selection}

Four young bulls were selected from a total of 113 male calves of population $1\left(F_{1}\right)$ from selected areas based on the result for average daily gain with consideration of physical appearance and libido. The expected response on average daily gain to selection of bulls from population 1 to population 2 is presented in Figure 1.

\section{Discussion}

\section{Birth weight}

The results of higher birth weight (26.12 \pm 8.26 $\mathrm{Kg})$ in Tungipara and lower one $(16.50 \pm 4.17 \mathrm{~kg})$ in Sariakandi (Table 2 ) revealed that the areas had a significant $(p<0.001)$ influence on birth weight of calves. The values on birth weight of male and female calves also differed significantly $(p<0.001)$. The maximum birth weight for male calves was $27.80 \pm 10.20 \mathrm{~kg}$ in Tungipara and minimum of $18.26 \pm 2.20 \mathrm{~kg}$ in Thakurgaon (Table 2 ). Similarly, the maximum birth weight of $23.33 \pm 3.51 \mathrm{~kg}$ for female calves was also in Tungipara and minimum of $17.48 \pm 2.06 \mathrm{Kg}$ in Thakurgaon (Table 2). The birth weight of Brahman crossed male and female calves averaged $21.38 \pm 4.98 \mathrm{~kg}$ (Table 5 ). This value was comparable to the value $(25.3 \mathrm{~kg})$ observed by Crockett et al. (1978). Sanders et al. (2005) observed $36.63 \mathrm{~kg}$ birth weight of $F_{1}$ Gray Brahman calves. Holloway et al. (2005) reported $33.50 \mathrm{~kg}$ birth weight of Brahman and Angus crosses. All estimated values greatly differed with the values of the present findings. This variation was probably due to use of Brahman bulls for crossing with the dams that were genetically superior to native cattle. Once more, environment also might have affected the result.

The average birth weight for male and female calves of $22.25 \pm 5.60 \mathrm{Kg}$ and $20.33 \pm 3.88 \mathrm{Kg}$, respectively (Table 5 ) was showed that the birth weight of male calves was $1.93 \mathrm{~kg}$, which was higher than the female one. These values closely related to the values of $2.1 \mathrm{~kg}$ and $2.00 \mathrm{~kg}$ as observed by Vargas et al. (1999) and Keith et al. (2010), respectively. Bhuiyan (1999) got comparatively higher birth weight for male and female $(27.50 \pm 0.79$ and $23.05 \pm 0.32 \mathrm{~kg}$, respectively) than the results of the present experiment while working on Friesian and Friesian $x$ Local grades of cattle.

Hirooka and Bhuiyan (1995) established mean birth weight for male and female of local and Friesian $x$ Local grades $13.44 \pm 1.782 \mathrm{~kg}$ and
$17.28 \pm 0.436 \mathrm{~kg}$, respectively. Habib et al. (2003) and Rabeya (2009) observed average birth weight of $16.7 \pm 0.48$ and $15.74 \mathrm{~kg}$, respectively for Red Chittagong cattle. All of their findings were lower than data obtained in the present study. Hoque et al. (1999) and Udo et al. (1990) obtained the birth weight of $17.92 \pm 3.47$ and $15.6 \pm .02 \mathrm{~kg}$, respectively in Pabna local cattle. Hossain and Routledge (1982) have also reported average birth weight of $16.37 \pm 0.20 \mathrm{~kg}$ in Pabna local. All of their given values were also lower than the present work.

It was observed that Brahman with local crossed calves were higher in average birth weight than the local or local crossed with improved genotypes. This might be due to better growth potentialities of Brahman cattle than others. The sex had an influence on birth weight of calves and majority of the cases males were heavier than the female ones, as would be expected.

\section{Yearling weight}

Maximum average yearling weight $401.11 \pm 39.75$ $\mathrm{Kg}$ was observed in Charghat and minimum $152.69 \pm 52.74 \mathrm{~kg}$ in Thakurgaon (Table 3). It was shown that areas had also highly significant $(p<0.001)$ influence on yearling weight of calves. In spite of the higher birth in Tungipara the yearling weight was higher in Charghat. Similarly, moderate birth weight was obtained in Jessore, but the yearling weight $(156.13 \pm 41.15 \mathrm{~kg})$ was lower than the values obtained from other areas. Accordingly, with some exception, it was observed that higher birth weight resulted greater yearling weight. The values on yearling weight of male and female calves from different areas differed significantly $(p<0.001)$. Among the male calves, the highest average yearling weight was $378.26 \pm 34.6 \mathrm{~kg}$ in Charghat and lowest one of $152.58 \pm 43.54 \mathrm{~kg}$ in Jessore. In female calves, the highest average yearling weight of $435.38 \pm 1.76 \mathrm{~kg}$ was also in Charghat and lowest one of $139.56 \pm 46.66 \mathrm{~kg}$ in Thakurgaon area.

The mean yearling weight of Brahman cross calves for male and female was $222.07 \pm 73.21$ and $191.76 \pm 69.04 \mathrm{~kg}$, respectively with pooled value of $208.07 \pm 72.74 \mathrm{~kg}$ (Table 5). Areas and sex also significantly $(p<0.001)$ affected on yearling weight. Sanders et al. (2005) worked on two (Angus and Brahman) $F_{1}$ crossed animal and found 271 and $270 \mathrm{~kg}$ yearling weight in Red Brahman and Gray Brahman crosses, respectively which were higher than the Angus crosses was $231 \mathrm{~kg}$, and obviously superior than present 
findings. All of these values greatly differed from the values of present experiment. Habib (2011) observed the mean yearling weight of Red Chittagong cattle for male and female calves as $70.6 \pm 0.70$ and $64.6 \pm 6.6 \mathrm{~kg}$, respectively, and average of male and female calves was $67.6 \pm 6.2$ kg. Rabeya et al. (2009) also worked on the same cattle and were obtained $76.2 \pm 4.0$ and $73.2 \pm 3.3 \mathrm{~kg}$ yearling weight for male and female, respectively. Guar et al. (2003) reported the mean yearling weight for Gir male and female was $138.5 \pm 0.52$ and $135.7 \pm 5.7 \mathrm{Kg}$, respectively and overall mean yearling weight was $137.0 \pm 4.9$ $\mathrm{kg}$. The yearling weight of Brahman crossed calves was larger resembling the findings from different workers stated above.

\section{Average daily gain}

It was observed that the areas had highly significant $(p<0.001)$ influence on average daily gain of calves. Despite the higher birth weight in Tungipara, the average daily gain was higher in Charghat. Similarly, moderate birth weight was obtained in Jessore but the rate of gain $(369.56 \pm 113.68 \mathrm{~g} / \mathrm{d})$ was lower than the values from different areas. In view of that, most of the cases higher the birth weight eventually greater in average daily gain. Highest average daily gain for male calves was obtained in Charghat $(968.750 \pm 82.68 \mathrm{~g})$, while lowest in Jessore $(357.31 \pm 121.03 \mathrm{~g})$. Similarly, highest average daily gain for female calves was obtained in Charghat (1133.93 $\pm 12.62 \mathrm{~g})$ and lowest in Thakurgaon (334.78 $\pm 124.59 \mathrm{~g}$ ) area.

The population mean of average daily gain of Brahman crosses was 511.81 $\pm 192.95 \mathrm{~g}$ (Table 5). Areas and sex had highly significant $(P<0.001)$ effect on average daily gain for calves. Colditz et al. (1972) and Keith et al. (2010) reported their experimental values of average daily gain as 670 and $849 \mathrm{~g}$, respectively. All of these values were distinctly higher than the value obtained in the present study. Habib et al. (2003) and Hossain and Routledge (1982) found the daily gain as 168 and $190 \mathrm{~g}$, respectively, which were lower than the present experiment. Habib (2011) estimated the pre-weaning and post-weaning mean weight gain in Red Chittagong calves of $157.5 \pm 15.9$ and $176.9 \pm .24 .3 \mathrm{~g} / \mathrm{d}$, respectively. All of these results were noticeably lower than the present work. This was probably due to genotypes and environmental variations, and evidently proved that Brahman crossed calves are better than the calves from the indigenous types/varieties.
The male calves were heavier than the female ones, and there was distinct positive effect of birth weight on average daily gain as well as on yearling weight of calves. Higher the birth weight, greater the yearling weight along with daily weight gain. Areas had significant influence on average daily gain of calves.

Selection differential for a given trait compares the average performance of selected individuals to the average of the population from which they were selected. Mean value for average daily gain of male calves of the population was found to be $547 \mathrm{~g}$ (Table 5), while the selected animals' mean was $731 \mathrm{~g}$. Thus, the estimated selection differential on average daily gain of selected breeding bulls from population 1 was found to be $183 \mathrm{~g}$ (Figure 1) with a selection intensity of 2.263. If these bulls be used properly for inseminating the cows of population 1 , the mean of population 2 might have been increased. The resulting expected response or genetic gain is shown in Figure 1.

\section{Conclusion}

The birth weight, yearling weight and average daily gain of Brahman crossed calves were higher than that of indigenous and other crossbred calves in Bangladesh as well as major part of the world. With some exception, higher the birth weight eventually greater in average daily gain and yearling weight, although management system of calves might have affected on these traits. The growth performance along with estimated selection intensity and selection differential for average daily gain of Brahman crossbred breeding bulls indicated that the selected bulls may create an exploitation opportunity to improve indigenous cattle for beef purposes in Bangladesh as well as sub-tropical regions. As the Brahman crossed cattle are a new introduction to Bangladesh, further in depth study is needed to explore more information from breed development approaches.

\section{References}

Bhuiyan MSA (1999). Estimation of genetic parameters for some economic traits of dairy cattle. MS Thesis, Department of Animal Breeding and Genetics, Bang. Agri. Univ., Mymensingh.

Colditz PJ and Kellaway RC (1972). The effect of diet and heat stress on feed intake, growth, and nitrogen metabolism in 


\section{Brahman crossbred bull selection}

Friesian, F1 Brahman $x$ Friesian, and Brahman heifers. Aus. J. Agri. Res. 23: 717-725.

Crockett JR, Koger M and Franke DE (1978). Rotational Crossbreeding of Beef Cattle: Preweaning Traits by Generation. J. Anim. Sci. 46: 1170-1177.

Guar OK, Kaushik SN and Garg RC (2003). The Gir cattle breed of India, Characteristics and present status. Anim. Gen. Resour. Inform. 33: 21-29

Habib MA, (2011). Analysis of Red Chittagong Cattle Genotype in Nucleus Breeding Herd, Ph.D dissertation, Department of Animal Breeding \& Genetics, Bang. Agri. Univ., Mymensingh.

Habib MA, Bhuiyan AKFH, Bhuiyan MSA and Khan AA (2003). Performance of Red Chittagong cattle in Bangladesh Agricultural University dairy farm. Bang. J. Anim. Sci. 32: 101-108.

Hirooka H and Bhuiyan AKFH (1995). Additive and heterosis effects on milk yield and birth weight from crossbreeding experiments between Holstein and Local breed in Bangladesh. Asian-Aus. J. Anim. Sci. 8: 295-300.

Hoque MA, Amin MR and Hussen MS (1999). Dairy potential of Pabna cows and crossbreds with Sahiwal and Friesian and within and between breed sire effect. Asian-Aus. J. Anim. Sci. 12: 161-164.

Hossain MA and Routledge SF (1982). Performance of crossbred and local cattle under village conditions in Pabna district of Bangladesh. Livest. Prod. Sci. 161-167.

Keith E Gregory, Gerald Smith M, Cundiff LV, Koch RM and Laster DB (2010). Characterization of biological types of cattle-cycle birth and weaning traits. J. Anim. Sci. 48: 271-279.

Majid MA, Nahar TN, and Jalil MA (1992). Breeding for cattle improvement in Bangladesh. Proc. 4th Nat. Conf., Bang. Anim. Hus. Assoc. P. 169-181

Rabeya T, Bhuyian AKFH, Habib MA and Hossain MS (2009). Phenotypic and genetic parameters on growth traits of Red Chittagong Cattle of Bangladesh. J. Bang. Agri. Univ. 7: 265271.

Sanders JO, Riley DG, Paschal J and Lunt DK (2005). Evaluation of the F1 Crosses of Five Bos indicus Breeds With Hereford for Birth, Growth, Carcass, Cow Productivity, and Longevity Characteristics Texas Agricultural Experiment Station and Texas A \& M University, College Station. P. 7843.

SAS (1998). User's guide. SAS Institute Inc. Version 6.12. Cary. United States of America.

Udo HMG, Hermans C and Dawood F (1990). Comparison of two cattle production system in Pabna district, Bangladesh. Tropical Anim. Health Prod., 22: 247-259.

Vargas CA, Olson TA, Chase CCJR, Hammond AC and Elzo MA (1999). Influence of frame size and body condition score on performance of Brahman cattle. J. Anim. Sci. 77: 3140. 